\title{
Bi-electrolyte Carbon Dioxide Gas Sensor Based on Paste Sodium-Beta Alumina and Yttria-stabilized Zirconia
}

\author{
Hyeuk Jin Han and Chong Ook Park ${ }^{+}$
}

\begin{abstract}
$\mathrm{CO}_{2}$ sensor was used only one solid electrolyte in many cases. To improve the sensing characteristics of $\mathrm{CO}_{2}$ sensors, solid electrolyte $\mathrm{CO}_{2}$ sensor has been developed by bi-electrolyte type sensor using Na-Beta-alumina and YSZ. However, in many further studies, bielectrolyte type sensor was made by pellet pressed by press machine and additional treatment for formation of interface. In the aspect of mass production, using thick film and additional treatment is not suitable. In this study, $\mathrm{CO}_{2}$ sensor was fabricated by bi-electrolyte structure which was made by an NBA paste layer deposited on YSZ pellet and fired at $1650^{\circ} \mathrm{C}$ for 2 hour. The formation of stable interface between YSZ and NBA were confirmed by SEM image. When the type IV electrochemical cell arrangement represented by $\mathrm{CO}_{2}, \mathrm{O}_{2}, \mathrm{Pt}\left|\mathrm{Li}_{2} \mathrm{CO}_{3}-\mathrm{CaCO}_{3}\right||\mathrm{NBA} \| \mathrm{YSZ}| \mathrm{O}_{2}$, Pt is used to measure the $\mathrm{CO}_{2}$ concentration in air. This sensor EMF should depend only on the concentration of $\mathrm{CO}_{2}$ by logarithmic. Also, sensor shows $\mathrm{P}_{\mathrm{CO}_{2}}$ and EMF relationship like nerstian reaction at a temperature of $450^{\circ} \mathrm{C}$.
\end{abstract}

Keywords: Gas sensors, Yttrium zirconium oxide, $\mathrm{Na}$ beta alumina, $\mathrm{CO}_{2}$, Paste

\section{INTRODUCTION}

As the importance of controlling $\mathrm{CO}_{2}$ increased in various technologies, the need of inexpensive $\mathrm{CO}_{2}$ sensor with high selectivity is growing. So the development of solid electrolyte $\mathrm{CO}_{2}$ sensor is required from the point of simplicity, low price and quantitative characteristic [1-3].

In this paper, to improve the sensing characteristics of $\mathrm{CO}_{2}$ sensors, solid electrolyte $\mathrm{CO}_{2}$ sensor has been developed by $\mathrm{Bi}$ electrolyte type sensor using Beta-alumina and YSZ which are super ionic conductor material have applied to the solid ion device for a long time [4]. In the bi-electrolyte $\mathrm{CO}_{2}$ sensor, a combination of $\mathrm{Na}^{+}$conductor of the Sodium-Beta-alumina (NBA) and Libased binary carbonate represented by $\mathrm{Li}_{2} \mathrm{CO}_{3}-\mathrm{CaCO}_{3}$ mixture were used as auxiliary electrode and $\mathrm{O}^{2-}$ conductor of $\mathrm{YSZ}$ was used as a reference material.

Following the Nernst equation, it reacted to $\mathrm{CO}_{2}$ rapidly and

Department of Materials Science and Engineering, Korea Advanced Institute of Science and Technology, E4 A304, Korea Advanced Institute of Science, 291, Daehak-ro, Yuseong-gu, Daejeon 305-701, Korea

${ }^{+}$Corresponding author: copark@kaist.ac.kr

(Received : May. 14, 2014, Revised : May. 23, 2014, Accepted : May. 26, 2014)

This is an Open Access article distributed under the terms of the Creative Commons Attribution Non-Commercial License(http://creativecommons.org/ licenses/bync/3.0) which permits unrestricted non-commercial use, distribution, and reproduction in any medium, provided the original work is properly cited. reversibly in $\mathrm{CO}_{2}$ concentration range $100 \sim 5000 \mathrm{ppm}$. The structure of this new type sensor was as followed.

$$
\mathrm{CO}_{2}, \mathrm{O}_{2}, \mathrm{Pt}\left|\mathrm{Li}_{2} \mathrm{CO}_{3}-\mathrm{CaCO}_{3}\|\mathrm{NBA}\| \mathrm{YSZ}\right| \mathrm{O}_{2}, \mathrm{Pt}
$$

However, in a further number of studies, bi-electrolyte sensor was prepared by pressing pellets and additional processing for forming an interface [5-7]. In the case of the mass production, the use of additional treatment and the pellet form is not suitable. Therefore, NBA paste was used in the process for connecting the electrolyte easily in this experiment.

\section{EXPERIMENTAL}

\section{1 $\mathrm{CO}_{2}$ Sensor Preparation}

The YSZ (TOSOH Corporation $8 \mathrm{~mol} \%$ ) pellet was made by applying a pressure of 2 tons about 1 minute at carver uni-axial press. After the molding, it was put in a bag of rubber and removed the air for 15 minutes. It applied a pressure of $29000 \mathrm{psi}$ at the CIP device (flow autoclave system). After creating a pellet, pellet was sintered at $1350^{\circ} \mathrm{C}$ for 8 hours. Fig. 1 shows the schematic structure of the prepared sensor.

Next, $\mathrm{Na}_{2} \mathrm{CO}_{3}$ (Aldrich) and $\mathrm{Al}_{2} \mathrm{O}_{3}$ (Aldrich) powders were weighed in a molar ratio of 1.2:11 for synthesizing Na-beta alumina. Then it was mixed ball milling in the bottle containing ethanol and zirconia ball for 1day. The resulting powder was dried 


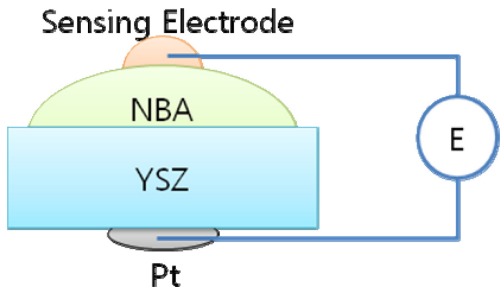

Fig. 1. Schematic structure of the $\mathrm{CO}_{2}$ sensor.
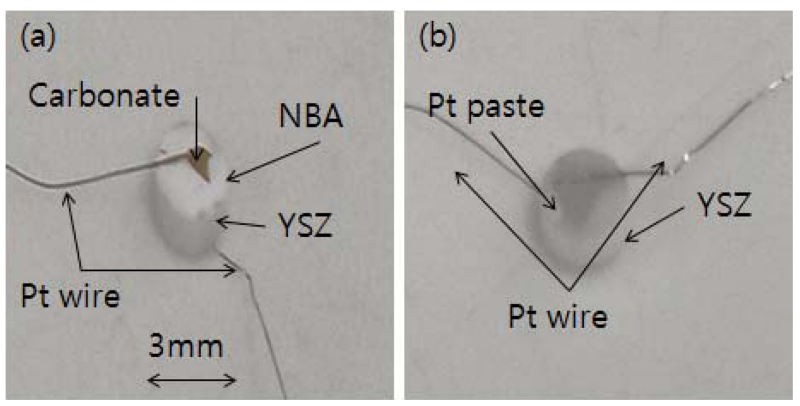

Fig. 2. Photographs of the fabricated $\mathrm{CO}_{2}$ sensor; (a) A top view and (b) bottom view.

and calcinated at $1650^{\circ} \mathrm{C}$ for one day. After calcinations, the powder was crushed by ball milling for 3 days. Final powder was obtained by drying and it was identified by X-ray diffraction.

NBA paste was put on the YSZ pellet and fired at $1650^{\circ} \mathrm{C}$ for 2 hour. Since NBA was put on top of the YSZ by paste form, SEM photographs were taken to confirm the formation of the interface between the YSZ and the NBA.

Then Pt paste and Pt wire was put in the bottom of YSZ and heat was treated at $1000^{\circ} \mathrm{C}$ for 1 hour. Mixture of $\mathrm{Au}, \mathrm{Li}_{2} \mathrm{CO}_{3}$ and $\mathrm{CaCO}_{3}$ paste was deposited on the NBA and Pt wire was put together. Then it was baked at $740^{\circ} \mathrm{C}$ for $15 \mathrm{~min}$. A view of the sensing element is shown in Fig. 2.

\section{2 $\mathrm{CO}_{2}$ Sensing Mechaninsm}

The mechanism of the sensor is very similar to the operation of Na-based carbonate electrodes [8]. The reaction of sensing electrode is assumed to be as follows,

$$
\begin{aligned}
& \mathrm{Li}_{2} \mathrm{CO}_{3}=2 \mathrm{Li}^{+}+\mathrm{CO}_{2}+(1 / 2) \mathrm{O}_{2}+2 \mathrm{e}^{-} \\
& 2 \mathrm{Na}^{+}+\mathrm{O}_{2^{-}}=\mathrm{Na}_{2} \mathrm{O} \text { (interface between NBA and YSZ) } \\
& (1 / 2) \mathrm{O}_{2}+2 \mathrm{e}^{-}=\mathrm{O}^{2-}(\mathrm{YSZ})
\end{aligned}
$$

The overall chemical reaction is written as

$$
\mathrm{Li}_{2} \mathrm{CO}_{3}+2 \mathrm{Na}^{+}=2 \mathrm{Li}^{+}+\mathrm{Na}_{2} \mathrm{O}+\mathrm{CO}_{2}
$$

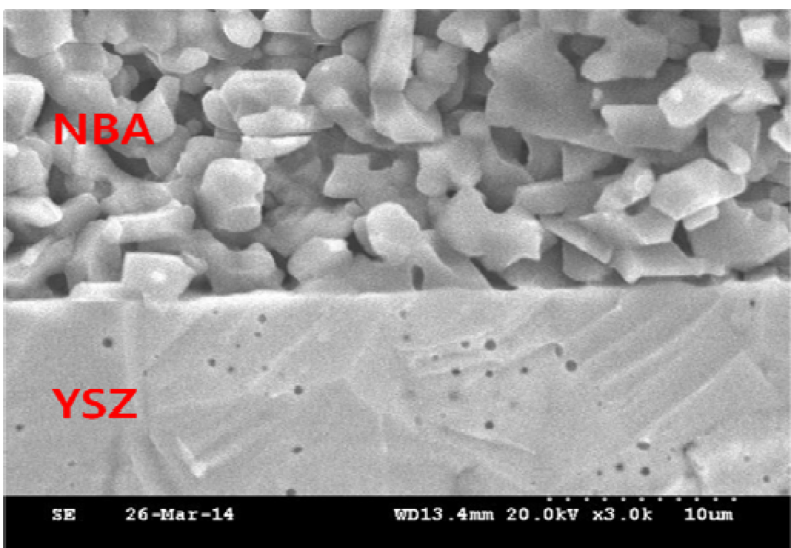

Fig. 3. Sensing performance of the $\mathrm{CO}_{2}$ sensor $\left(450^{\circ} \mathrm{C}\right)$.

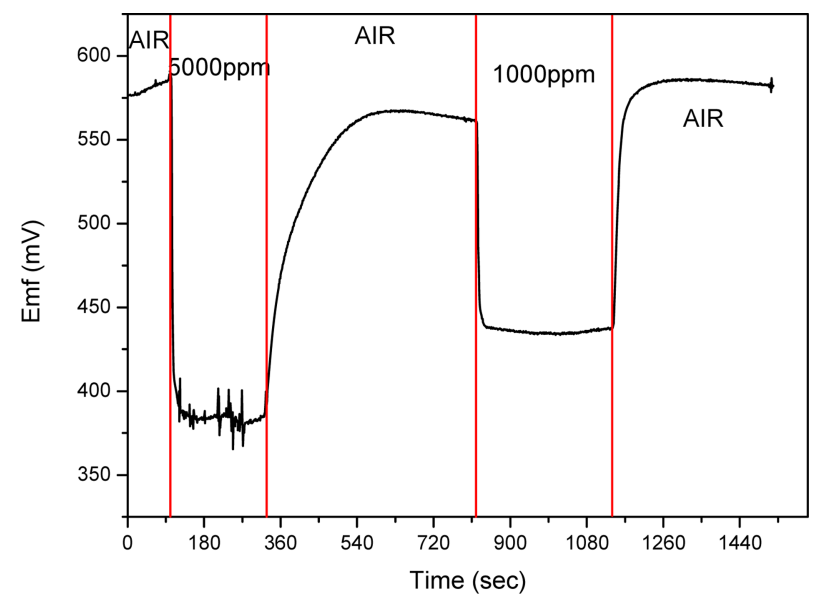

Fig. 4. Interface between NBA and YSZ.

Assumed by the constant activities of $\mathrm{Li}_{2} \mathrm{CO}_{3}, \mathrm{Na}^{+}, \mathrm{Li}^{+}$and $\mathrm{Na}_{2} \mathrm{O}$, EMF can be expressed as

$$
\mathrm{E}=\mathrm{E}_{0}-(\mathrm{RT} / 2 \mathrm{~F}) \ln \mathrm{P}\left(\mathrm{CO}_{2}\right)
$$

The $\mathrm{CO}_{2}$ sensing properties were examined at $450^{\circ} \mathrm{C}$. As shown in Fig. 4, the sensor reacted well to changing from dry air $(0 \mathrm{ppm}$ $\mathrm{CO}_{2}$ ) to dry $5000 \mathrm{ppm} \mathrm{CO}_{2}$ and $1000 \mathrm{ppm} \mathrm{CO}_{2}$. The sensor responded well to dry air at recovery state.

\section{RESULTS AND DISCUSSIONS}

This sensor was made by printing paste on the YSZ pellet rather than the Miura method which is classic method for joined to each other electrolyte by using Pt-wire spring system. Therefore it is necessary to confirm that interface between NBA and YSZ. As shown in Fig. 3, NBA paste film and YSZ form interface between NBA and YSZ. 
Fig. 4 shows the response of the $\mathrm{CO}_{2}$ sensor at $450^{\circ} \mathrm{C}$. When the partial pressure of $\mathrm{CO}_{2}$ is changed, the EMF changed and reaches a constant value within $200 \mathrm{~s}$. The response is quite rapid because the time of $200 \mathrm{~s}$ is necessary to change the gas composition in the testing tube.

Sensitivity were $71.54 \mathrm{mV} / \mathrm{dec}$ at $450^{\circ} \mathrm{C}$. This value shows only $1 \%$ error compare to the result of a theoretical value $(71.73 \mathrm{mV} /$ dec) that came out in the previous equation (6). As a conclusion, E vs. $\log \mathrm{P}_{\mathrm{CO} 2}$ shows a linear relationship obeying the Nernst law for $450^{\circ} \mathrm{C}$.

\section{CONCLUSIONS}

$\mathrm{CO}_{2}$ sensor was fabricated by bi-electrolyte structure that the NBA paste painted on top of the YSZ pellet. Without any special mechanical forces, it was possible to confirm the formation of stable interface by heat treatment using a simple paste.

$\mathrm{P}_{\mathrm{CO}_{2}}$ and EMF relationship were showed nerstian reaction with the theoretical relationship at a temperature of $450^{\circ} \mathrm{C}$. It functions as $\mathrm{CO}_{2}$ sensors in which EMF are expressed by eq. (6). Also, sensitivity Error compare to theoretical value is approximately $1 \%$.

In the future, on the basis of this result, $\mathrm{CO}_{2}$ sensor will produced by typecasting method because typecasting can make sensor more cheap and easy to approach mass production.

\section{REFERENCES}

[1] M. Gauthier and A. Chamberland, "Solid-state detectors for the potentiometric determination of gaseous oxides", $J$. Eletrochem. Soc., Vol. 124, pp. 1579-1583, 1977.

[2] Y. Saito and T. Maruyama, "Recent developments of the sensors for carbon oxides using solid electrolytes", Solid State Ion., Vol. 28-30, pp. 1644-1647, 1988.

[3] S. Yao, S. Hosohara, Y. Shimizu, N. Miura, H. Futata, and N. Yamazoe, "Solid electrolyte $\mathrm{CO}_{2}$ sensor using NASICON and Li-based binary carbonate electrode", Chem. Lett., Vol. 20, pp. 2069-2072, 1991.

[4] H. Näfe, "On the electrode reaction of the $\mathrm{Au} \mid \mathrm{CO}_{2}, \mathrm{O}_{2}$, $\mathrm{Me}_{2} \mathrm{CO}_{3}(\mathrm{Me}=\mathrm{Li}, \mathrm{Na}, \mathrm{K}) \mid$ Yttria-stabilized zirconia electrode", Journal of Electrochemical Society, Vol. 144, pp. 915-922, 1997.

[5] T. Maruyama, and S. Sasaki, "Potentiometric gas sensor for carbon dioxide using solid electrolytes", Solid State Ion., Vol. 23, p. 107, 1987.

[6] H. Nafe "Thermodynamic conditions at the interface between Na-beta- alumina and stabilized zirconia in a bielectrolyte galvanic cell”, Solid State Ion., Vol. 93, pp. 117123, 1997.

[7] G. M. Kalea, L. Wang, and Y. R. Hong, "Planar SOX sensor incorporating a bi-electrolyte", Solid State Ion., Vol. 161, p. 155, 203.

[8] S. Yao, Y. Shimizu, N. Miura, and N. Yamazoe, "Solid electrolyte $\mathrm{CO}_{2}$ sensor using binary carbonate electrode", Chem. Lett., Vol. 19, pp. 2033-2036, 1990. 